\title{
Long-term Residual Effects of Nitrogen Fertilization on Western Wheatgrass
}

\author{
LARRY M. WHITE
}

Abstract

Nitrogen $(N)$ fertilization can be an effective way of increasing forage production. The question is how much does $\mathbf{N}$ fertilization increase forage yield of western wheatgrass (Agropyron smithii) when there is not a shift in species composition as occurs when $\mathbf{N}$ is applied to a native range site. The objectives of this research were to determine the residual effects of a single applieation of (1) 6 geometric rates of $\mathbf{N}$ and phosphorus (P) on forage yield, in vitro dry matter digestibility (IVDMD), crude protein (CP), and phosphorus $(P)$ concentration (conc) of western wheatgrass grown near Sidney, Mont. during a 10-year period. Ammonium nitrate was applied at $0,40,80,160,320$, and $640 \mathrm{~kg} N /$ ha in March 1973 and triple super phosphate at $45 \mathrm{~kg} P / \mathrm{ha}$ on split plots during August 1975. A single application of $N$ increased forage yield by $0.0,0.0$, $0.95,0.35,0.0,1.16,0.52$, and $1.41 \mathrm{~kg} / \mathrm{ha}$ per $\mathrm{kg}$ of $\mathrm{N}$ applied the 1st, 2nd, 3rd, 4th, 5th, 6th, 7th, and 10th year sampled, respectively, regardless of $\mathbf{N}$ rate. Nitrogen fertilization increased the accumulative forage $(P<0.01)$ and $C P(P<0.01)$ yield over the 8 harvest-years by 4.35 and $0.87 \mathrm{~kg} / \mathrm{ha}$ per $\mathrm{kg}$ of $\mathrm{N}$ applied. Nitrogen fertilization increased the average forage IVDMD by 0.1 percentage units $(P<0.05)$ and decreased $P$ conc by 0.03 percentage units per $100 \mathrm{~kg} \mathrm{~N} / \mathrm{ha}$ applied $(P<0.01)$. Application of $45 \mathrm{~kg} \mathrm{P} / \mathrm{ha}$ in 1975 increased the $P$ conc of the forage an average of 0.04 percentage units each year, increased forage yield only the 10th year by $150 \mathrm{~kg} / \mathrm{ha}$, and had no effect on IVDMD or CP. This study also showed that long-term observations are necessary to measure the residual effects of fertilization.

Nitrogen $(\mathbf{N})$ fertilization can effectively increase forage production in the northern Great Plains. Annual applications of 35 to 55 $\mathrm{kg} \mathrm{N} /$ ha have doubled forage production of native range plant communities (Wight 1976). Read (1969), Wight and Black (1979), and Power (1981) found that a single application of $\mathbf{N}$ to native range in the Northern Great Plains increased forage yields for 4 to 6 years. However, they did not know what proportion of the forage increase was due to residual $N$ per se or to a shift in species composition. Nitrogen fertilization has generally increased the composition of cool-season species such as western wheatgrass (Agropyron smithii) and decreased warm-season species such as blue grama (Bouteloua gracilis) (Rogler and Lorenz 1965). Forage yield increases from $\mathbf{N}$ fertilization on native range are probably largely due to a species shift. No literature was found on the long-term effects of a single application of $\mathrm{N}$ fertilizer on a monoculture of western wheatgrass.

Nitrogen fertilization has had variable effects on forage quality. No literature was found on the effects of $\mathbf{N}$ fertilization on digestibility of western wheatgrass forage. Studies have shown that $N$ fertilization increased the in vitro dry matter digestibility (IVDMD) of bermudagrass (Cynodon dactylon) (Fribourg et al. 1971, Taliaferro et al. 1975), weeping lovegrass (Eragrostis curvula), and old world bluestem (Bothriochloa ischaemum var. ischaemum)(Taliaferro et al. 1975). However, other studies have shown that $N$ fertilization had no effect on the IVDMD of reed canarygrass (Phalaris arundinacea) (Niehaus, 1971), bromegrass (Bromus inermis), orchardgrass (Dactylis glomerata), and timothy (Phleum

Author is a range scientist, USDA-ARS, Southern Plains Range Research Station, 2000-18th St., Woodward, Okla. 73801. At the time of the research, ranch scientist, USDA-ARS, Northern Plains Soil and Water Res. Center, Sidney, Montana.

This article is a contribution from U.S. Department Agriculture, Agricultural Research Service.

Manuscript accepted March 25, 1985. pratense) (Calder and MacLeod 1968) and decreased IVDMD of Italian ryegrass (Lolium multiflorum) (Binnie et al. 1974). Nitrogen fertilization has generally increased the crude protein (CP) concentration (conc) of western wheatgrass grown on native range (Black and Wight 1979; Rogler and Lorenz 1965). Black (1968) found that application of $\mathrm{N}$ on a native range reduced the phosphorus $(P)$ conc of the forage. He found that application of $P$ fertilizer significantly increased the $P$ conc in the forage from 0.10 to $0.12 \%$.

The objectives of this research were to determine the residual effects of a single application of (1) 6 geometric rates of $N$ and (2) one rate of $P$ on forage yield, IVDMD, CP, and $P$ conc of western wheatgrass forage grown near Sidney, Mont. during a 10-year period.

\section{Materials and Methods}

The study site was $7 \mathrm{~km}$ southeast of Sidney, Mont. at an elevation of $610 \mathrm{~m}$. 'Rosana' western wheatgrass was seeded on a Shambo loam soil (Typic Haploborolls, fine-loamy, mixed) in September 1971 on land summer fallowed for 2 years $(1970,1971)$. Analysis of the 0 to $7.5-\mathrm{cm}$ depth of soil in March of 1973 showed that $\mathrm{pH}$ of a saturated paste was 8.0 and conductivity was 0.5 mmhos $/ \mathrm{cm}$; organic matter, $3.9 \%$; sodium bicarbonate-extractable $P, 11 \mathrm{ppm}$; ammonium acetate-extractable $\mathrm{K}, 440 \mathrm{ppm}$; and exchangeable $\mathrm{Ca}, \mathrm{Mg}$, and $\mathrm{Na}$, was 14,3 , and $0.5 \mathrm{meq} / 100 \mathrm{~g}$, respectively. The site had previously grown small grains for a number of years. Average annual precipitation (PT) at the site was $345 \mathrm{~mm}$ with $21 \%$ received from October through March, $44 \%$ from April through June, and 35\% from July through September. January and July long-term mean temperatures were -13 and $20^{\circ}$ $C$ respectively, and the average frost-free period was 122 days. Additional details of the study site were previously reported in publications on effects on $\mathrm{N}$ fertilization rates on conc of nitrate- $\mathrm{N}$ (White and Halvorson 1980); major cations (Halvorson and White 1981 ); and minor cations (Halvorson and White 1983) of western wheatgrass during 1973 and 1974.

A single application of ammonium nitrate was broadcast at 0 , $40,80,160,320$, and $640 \mathrm{~kg} \mathrm{~N} /$ ha on plots 5 by $6 \mathrm{~m}$ in late March 1973. Plots were arranged in a randomized complete-bock design with four replications. Because of low forage yield response to $\mathrm{N}$ fertilization in 1973 through 1975 and the fact that sodium bicarbonate-extractable soil $P$ in the 0 to $7.5-\mathrm{cm}$ depth was only 11 ppm (bottom of the moderate range) plots were split in August 1975 and half of each plot, selected randomly, was broadcast fertilized with $45 \mathrm{~kg} \mathrm{P} / \mathrm{ha}$ as triple super phosphate to determine if $P$ fertilization would increase the forage yield response to $N$ fertilization. Western wheatgrass forage at anthesis was harvested to a $5-\mathrm{cm}$ height from a 0.35 - by $4-\mathrm{m}$ area yearly from 1973 through 1979 , and 1982. Forage from the remainder of the plot was also harvested a few days later and removed. Plant material was dried at $70 \mathrm{C}$ for 48 hours and ground to pass a $1-\mathrm{mm}$ screen before analysis.

The IVDMD was determined by a modification of the Tilley and Terry two-stage method as previously described by White et al. (1981). Nitrogen conc was determined by the macro-Kjeldahl method. Nitrogen was multipled by 6.25 to estimate CP. The $P$ conc was determined by wet digesting the forage samples with perchloric-sulfuric acid on a block digestor. The digest was ana- 
lyzed with an autoanalyzer by vanadate-molybdate method.

Soil nitrate levels were determined by compositing two soil cores taken one meter apart from each plot in 30-cm-depth increments to $0.6 \mathrm{~m}$ depth in March 1973 and to $1.2 \mathrm{~m}$ depth in October 1973 and 1974.

Daily PT was measured at the site from April through October in a standard $20-\mathrm{cm}$ diameter rain gauge. The PT data from November through March were obtained from an official weather station $7 \mathrm{~km}$ away which was located on similar topography. Soil water (SW) content by $30-\mathrm{cm}$ increments from 0 - to $270-\mathrm{cm}$ depth was determined every two weeks from late April through July each year from 1973 through 1982 with a neutron probe in nonfertilized plots. Evapotranspiration (ET) was defined as the net $S W$ loss in the 0 - to $120-\mathrm{cm}$ profile plus $P T$ received from late April through anthesis (about June 30) (PTa-j) each year. The SW data showed that there was no evidence of $S W$ percolation below $120 \mathrm{~cm}$ depth. There was no evidence of surface runoff during the study.

The effects of $\mathbf{N}$ and $\mathbf{P}$ fertilization each year on forage yield, IVDMD, CP, and $P$ conc in the forage were analyzed with an analysis of variance using a split plot in space design. Since $\mathbf{P}$ fertilization had no effects on forage yield (except in 1982), IVDMD, and $C P$ the data from the $P$ fertilized plots was deleted and an analysis of variance was run only on data without $P$ fertilization over years using a split plot in time design. The effects of $\mathbf{N}$ fertilization on treatments means was partitioned into linear, quadratic, cubic, and residual components (Steel and Torrie 1960). Since the year-by- $\mathbf{N}$ interaction was significant for all except IVDMD, a 2-way analysis of variance was also conducted separately for each set of data each year. Treatment effects were again partitioned into linear, quadratic, cubic and residual components. Forage yield, digestible forage yield, total $\mathrm{N}$ and $\mathrm{P}$ harvested in the forage each year were accumulated over years and the increase over the check $(0 \mathrm{~N})$ plot for each replication was also analyzed with a 2-way analysis the same as described above. Stepwise (addition) multiple regression was used to determine whether PT from late April through June (PTa-j), SW used from late April through June (SWa-j), or ET from late April through June (ETa-j) was most closely correlated with nonfertilized forage yields of western wheatgrass. All differences mentioned in this paper are significant at the $P<0.05$ probability level unless other stated.

\section{Results and Discussion}

\section{Forage Yield}

Lack of PT for a month after fertilization (20 Mar. 1973 until late April, 1973) limited the response of western wheatgrass to $\mathbf{N}$ fertilization the first year and may have caused some volatilization of the surface applied ammonium nitrate. The PTa-j was above average for all study years except 1977 and 1979 (Table 1).
Table 1. Precipitation, soil water used, ET (late April through June) and forage yield of western wheatgrass grown without $\mathrm{N}$ fertilization during a 10-year period near Sidney, Mont.

\begin{tabular}{|c|c|c|c|c|c|c|}
\hline \multirow[b]{2}{*}{ Year } & \multicolumn{3}{|c|}{ Precipitation } & \multirow{2}{*}{$\begin{array}{l}\text { Soil water } \\
\text { used } \dagger^{+}\end{array}$} & \multirow{2}{*}{$\begin{array}{c}\text { Total } \\
\text { ET }\end{array}$} & \multirow{2}{*}{$\begin{array}{c}\text { Forage } \\
\text { yield }\end{array}$} \\
\hline & Oct-Dec $\dagger$ & Jan-Mar & Apr-Jun & & & \\
\hline & & & $-\mathbf{m m}$ & & & $\mathrm{kg} / \mathrm{ha}$ \\
\hline 1973 & 36 & 15 & 167 & +30 & 197 & 1630 \\
\hline 1974 & 38 & 35 & 167 & +16 & 183 & 1850 \\
\hline 1975 & 36 & 41 & 173 & +47 & 220 & 2320 \\
\hline 1976 & 76 & 28 & 175 & +12 & 187 & 880 \\
\hline 1977 & 30 & 25 & 99 & +32 & 131 & 330 \\
\hline 1978 & 63 & 46 & 178 & -9 & 169 & 1250 \\
\hline 1979 & 48 & 43 & 83 & +64 & 147 & 520 \\
\hline 1982 & 41 & 76 & 150 & +39 & 189 & 1480 \\
\hline Avg. & 46 & 38 & 149 & +29 & 178 & 1282 \\
\hline
\end{tabular}

$\dagger$ previous year

†† late April through anthesis

A single application of $\mathrm{N}$ fertilizer did not consistently increase forage yields of western wheatgrass over the 8-years harvested (significant year-by-N interaction) (Table 2). Nitrogen fertilization in March of 1973 did not increase forage yields the $1 \mathrm{st}$, 2nd, or 5 th years, but did increase them each of the other five years (Fig. 1). Apparently residual $\mathbf{N}$ from two years of summer fallowing masked the fertilizer $\mathbf{N}$ response the first two years. Drought the 5 th year prevented a $\mathrm{N}$ fertilizer response. A single application of $\mathrm{N}$ increased forage yields by $0.95,0.35,1.16,0.52$, and $1.41 \mathrm{~kg} / \mathrm{ha} \mathrm{per}$ $\mathrm{kg}$ of $\mathrm{N}$ applied during the $3 \mathrm{rd}$, 4th, 6th, 7th, and 10th years harvested, respectively, regardless of the $\mathrm{N}$ rate applied (Table 2 and Fig. 1). Wight and Black (1979) found that a single application of 112 and $336 \mathrm{~kg} \mathrm{~N} /$ ha to native range increased averaged forage yields over the next 8 years by 4.2 and $2.3 \mathrm{~kg} /$ ha per $\mathrm{kg}$ of $\mathrm{N}$ applied. This is over twice the $0.55 \mathrm{~kg} /$ ha average increase found for seeded western wheatgrass. Wight and Black (1979) found that the forage yield response was the greatest the first year after application $(6.4 \mathrm{~kg} / \mathrm{ha})$ then gradually decreased to $1.5 \mathrm{~kg} / \mathrm{ha}$ by the eighth year. In contrast seeded western wheatgrass response was the greatest the 10th year after application.

Mason and Miltimore (1972) were the only other researchers to find that residual effects of a single application of low rates of $\mathrm{N}$ increased forage yields for more than 10 years. Power (1981) found that application of less than $270 \mathrm{~kg} \mathrm{~N} /$ ha only increased native forage yield 1 to 3 years in a 10 year study. Kilcher et al. (1965) and Read (1969) found that residual effects from low rates of $\mathrm{N}$ lasted as long as their studies, 4 and 6 years, respectively. Application of over $300 \mathrm{~kg} \mathrm{~N} /$ ha has increased native forage yield for over 8 years in 8- to 10-year studies (Smoliak 1965, Wight and Black 1979, Power 1981).

Table 2. Summary of forage yield, IVDMD, $C P$, and $P$ conc of westem wheatgrass response surface ( $L=l i n e a r, ~ Q=q u a d r a t i c, ~ C=c u b i c)$ to a single application of $0,40,80,160,320$, and $640 \mathrm{~kg} \mathrm{~N} / \mathrm{ha}$ fertilizer in 1973 without $P$ fertilization.

\begin{tabular}{|c|c|c|c|c|c|c|}
\hline \multirow[b]{2}{*}{ Year } & \multicolumn{2}{|c|}{ Forage Yield } & IVDMD & $\mathbf{C P}$ & \multicolumn{2}{|c|}{$\mathbf{P}$} \\
\hline & Sig. & $r^{2}$ & Sig. $r^{2}$ & Sig. $r^{2}$ & Sig. & $\mathbf{r}^{2}$ \\
\hline 1973 & NS & - & & ${ }^{*} \mathrm{~L} \quad 0.79$ & NS & - \\
\hline 1974 & NS & - & & $* \mathrm{~L} \quad 0.84$ & NS & - - \\
\hline 1975 & ${ }^{*} \mathrm{~L}$ & 0.47 & & ${ }^{*} \mathrm{Q} \quad 0.98$ & ${ }^{*} \mathbf{L}$ & 0.38 \\
\hline 1976 & $* * L$ & 0.95 & & $* * \bar{Q}$ & NS & - \\
\hline 1977 & NS & -1 & & $*_{\mathrm{L}} \quad 0.93$ & NS & - \\
\hline 1978 & $* *_{L}$ & 0.95 & & $* \bar{L} \quad 0.99$ & ${ }^{*} \mathrm{~L}$ & 0.77 \\
\hline 1979 & $* *_{\mathrm{L}}$ & 0.67 & & $* * \bar{C}$ & ${ }^{*} \mathrm{Q}$ & 0.91 \\
\hline 1982 & $* * L$ & 0.95 & & $* Q \quad 0.98$ & $* * \mathrm{~L}$ & 0.72 \\
\hline NXY Inter. & $* *$ & - - & NS - & $* * \quad-$ & $* *$ & - - \\
\hline $\mathrm{N}$ overall & - & - - & ${ }^{*} \mathrm{~L} \quad 0.89$ & --- & - & - \\
\hline
\end{tabular}

NS, *nonsignificant $(P<0.05)$, significant $(P>0.05)$, or highly significant $(P>0.01)$ response surface to $\mathrm{N}$ fertilization. 


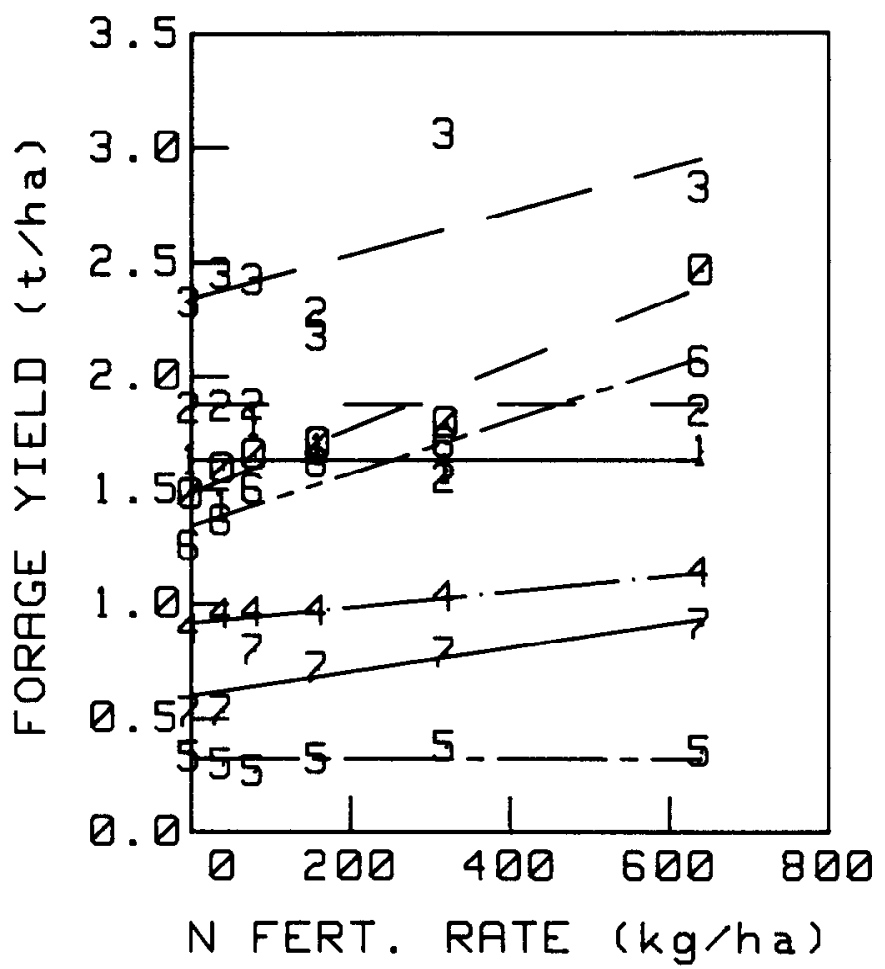

Fig. 1. Forage yield of western wheatgrass near Sidney, Mont. during a 10-year period (numbers on lines represent years, $0=10$ th year) as affected by a single application of $0,40,80,160,320$, and $640 \mathrm{~kg} \mathrm{~N} /$ ha fertilizer in 1973.

Each $\mathrm{kg} \mathrm{N} /$ ha applied in 1973 increased the accumulative forage yields over the 8-harvest years an average of $4.35 \mathrm{~kg} / \mathrm{ha}$ (Equation l).

Increased forage $(\mathrm{kg} / \mathrm{ha})=256.4+4.35 \times \mathrm{N}$ rate $(\mathrm{kg} / \mathrm{ha}), \mathrm{r}^{2}=0.9$

There was no difference in the efficiency of $\mathbf{N}$ use between the different $\mathbf{N}$ rates. Apparently the effects of $\mathbf{N}$ fertilization applied in 1973 will continue for more than 10 years as evidenced by 1982 yields (Fig. 1). Low PT limited the forage yield but when normal PT was received the residual $N$ increased forage yields.

In August 1975, plots were split and $45 \mathrm{~kg} \mathrm{P/ha}$ was applied to half of each plot to determine if $P$ was limiting the $N$ fertilizer response. The $P$ fertilization did not affect forage yields of western wheatgrass in 1976, 1977, 1978, but significantly increased it by 150 $\mathrm{kg} / \mathrm{ha}$ in 1982 . Wight and Black (1979) reported that single appli- cation of up to $224 \mathrm{~kg} \mathrm{P/ha}$ on native range near Sidney, Mont. increased forage yield over the next 8 years by $20 \%$.

\section{Evapotranspiration}

Stepwise regression showed that ETa-j was more highly correlated $(P<0.05$ ) with nonfertilized forage yield during the 8 years harvested than was PTo-d, PTj-m, PTa-j, SWa-j used, or reciprocal of stand age (years). Variation of $E T a-j$ only accounted for $56 \%$ of the variation in forage yield. The second most important variable was PTo-d of the previous year. Variation of ETa-j and PTo-d together accounted for $65 \%$ of the variation in forage yield during the 8 years harvested. Eliminating the first two years of data (1973 and 1974), ETa-j then accounted for $74 \%$ of the variation and ETa-j plus PTo-d together accounted for $79 \%$ of the variation (Equation 2).

Forage yield $(\mathrm{kg} / \mathrm{ha})-1658+18.6 \mathrm{ETa}-\mathrm{j}(\mathrm{mm})-9.3 \mathrm{PTo}-\mathrm{d}(\mathrm{mm}), \mathrm{r}^{2}=0.79$

It was surprising to find that the coefficient for PTo-d was negative, suggesting decreased forage yield the following year. PTa-j was excluded from the stepwise regression model after ETa-j was selected.

The amount that $\mathbf{N}$ fertilization increased forage yields from the 1st through 10th year was not significantly correlated with ETa-j $\left(r^{2}=.27\right)$. Variation in ETa-j and forage yield increases from $\mathbf{N}$ fertilization apparently were not correlated because of the residual effects of summer fallowing for 2 years and stand age. White (1985) showed that forage yields of four grasses were higher per $\mathrm{cm}$ of PTa-j received during the first few years after establishment than in subsequent years. The effects of $\mathbf{N}$ fertilization on water-use efficiency can not be determined since $\mathrm{SW}$ was measured only on the nonfertilized plots.

\section{Soil Nitrate-N}

Two years of summer fallowing mineralized $68 \mathrm{~kg} /$ ha of nitrate$\mathrm{N}$ in the 0- to 60-cm depth as of March 1973 (Table 3). If it is assumed that the soil nitrate present in October 1974 was similar to that present in March 1973 then an additional $40 \mathrm{~kg} /$ ha nitrate-N would be present in the $60-$ to $120-\mathrm{cm}$ depth making a total in the profile of $108 \mathrm{~kg} / \mathrm{ha}$. Western wheatgrass used most of the applied $\mathrm{N}$ in the 0 - to $30-\mathrm{cm}$ depth and there was a marked accumulation in the $30-$ to $60-\mathrm{cm}$ depth both in 1973 and 1974 . There was an average of $64 \mathrm{~kg}$ / ha more nitrate-N present in October 1974 than October 1973 when averaged over all $N$ fertilization rates. The large increase in new roots the second year after seeding could have immobilized rather substantial amounts of nitrate-N which was later released. Over half of the applied $\mathbf{N}$ was not found as soil nitrate-N after application (Table 3). Power (1972) also found that about half of the $\mathbf{N}$ applied to native grass was either immobilized

Table 3. Soil nitrate- $\mathrm{N}$ levels by $30-\mathrm{cm}$ depth increments present before and after $\mathbf{N}$ fertilization of western wheatgrass.

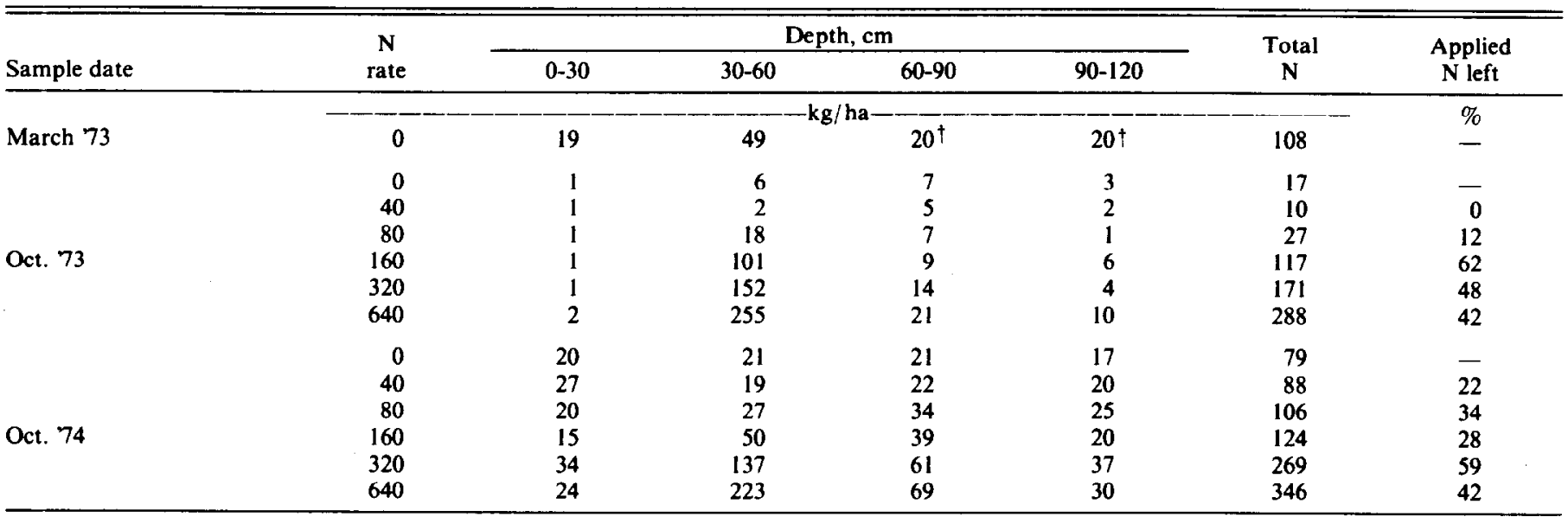

\footnotetext{
+ Estimated assuming that soil nitrate-N value measured in 1974 at 60 - to $90-$ to $120-\mathrm{cm}$ depths were similar to those present in March 1973 .
} 


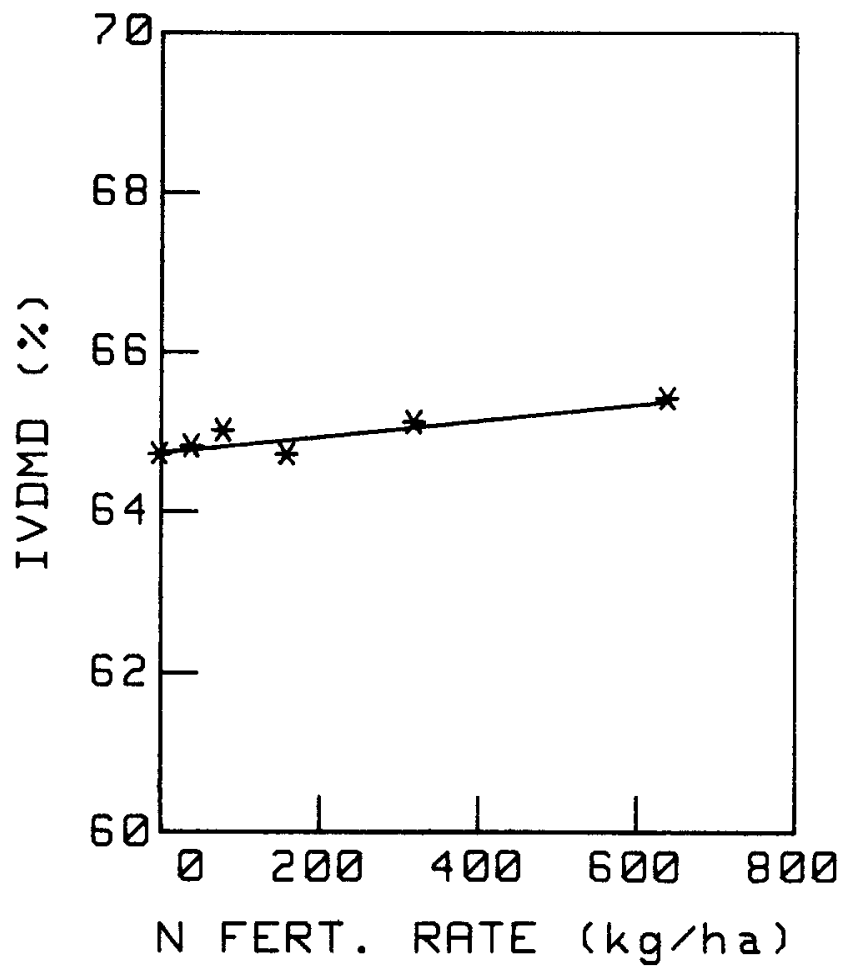

Fig. 2. Average IVDMD of western wheatgrass near Sidney, Mont. during a 10-year period as affected by a single application of $0,40,80,160,320$, and $640 \mathrm{~kg} \mathrm{~N} /$ ha fertilizer in 1973.

or lost. Power and Legg (1984) found that growing conditions the first month or two after $\mathbf{N}$ application had a greater influence on $\mathrm{N}$ recovery than other factors. However, they found that recovery of tagged $\mathrm{N}$ was greater in drier than wetter years.

\section{Digestibility}

Addition of each $100 \mathrm{~kg} \mathrm{~N} /$ ha fertilizer significantly increased IVDMD 0.1 percentage units (Equation 3, Fig. 2). There was no

$$
\operatorname{IVDMD}(\%)=64.74+0.001 \times \mathrm{N} \text { rate }(\mathrm{kg} / \mathrm{ha}), \mathrm{r}^{2}=0.80
$$

significant interaction between years and $\mathrm{N}$ rates which indicates that $\mathbf{N}$ fertilization increases IVDMD the same over all years (Table 2). Application of each $\mathrm{kg} \mathrm{N} /$ ha significantly increased the accumulative digestible forage yield linearly over the 8 years harvested by $2.9 \mathrm{~kg}$ (Equation 4). Application of $P$ fertilizer had no

$$
\text { Dig. yield }(\mathrm{kg} / \mathrm{ha})=154.3+2.90 \times \mathrm{N} \text { rate }(\mathrm{kg} / \mathrm{ha}), \mathrm{r}^{2}=0.95
$$

significant effects on the IVDMD of western wheatgrass during the 3 years it was measured $(1976,1978,1982)$.

The IVDMD of nonfertilized western wheatgrass forage averaged $65.6,65.3,62.2,63.6,66.5,65.6,65.1$, and $65.7 \%$ the 1 st, $2 \mathrm{nd}$, 3 rd, 4th, 5th, 6th, 7th, and 10th years, respectively. Regression analysis showed that average IVDMD of nonfertilized forage decreased 1.0 percentage units per every $1000 \mathrm{~kg} / \mathrm{ha}$ increase in forage yield which is about half of that found for introduced grasses near Sidney, Mont. during the same period (White and Wight 1984).

\section{Crude Protein}

The single application of $\mathrm{N}$ in March of 1973 significantly increased CP conc in western wheatgrass all years but there was a significant year-by-N rate interaction (Table 2 and Fig. 3). During the first two years, $\mathrm{N}$ fertilization increased $\mathrm{CP}$ linearly, during the 3rd and 4th years $N$ increased $C P$ more per unit of $N$ applied at the

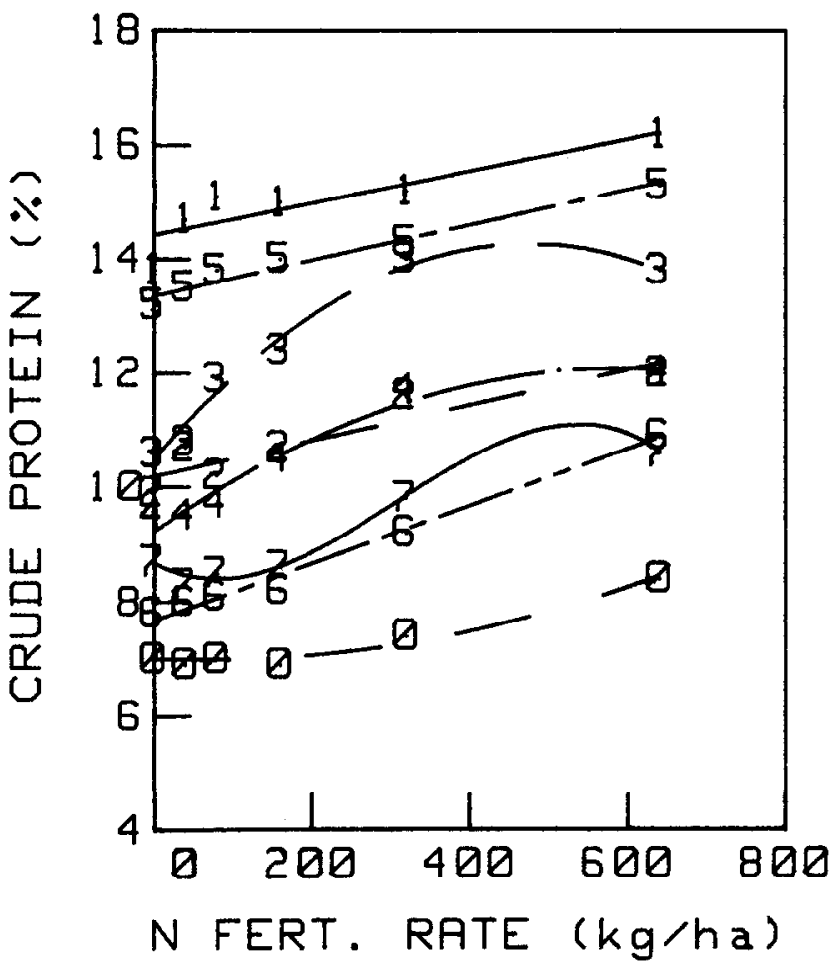

Fig. 3. Crude protein of western wheatgrass near Sidney, Mont. during a 10 -year period (numbers on lines represent years, $0=10$ th year) as affected by a single application of $0,40,80,160,320$, and $640 \mathrm{~kg} \mathrm{~N} /$ ha fertilizer in 1973.

lower rates than at the higher rates. However during the 5th and 6th years, $\mathrm{N}$ fertilization increased $\mathrm{CP}$ linearly and during the 7 th and 10th years the lower rates produced less CP per unit of $N$ applied than the higher rates.

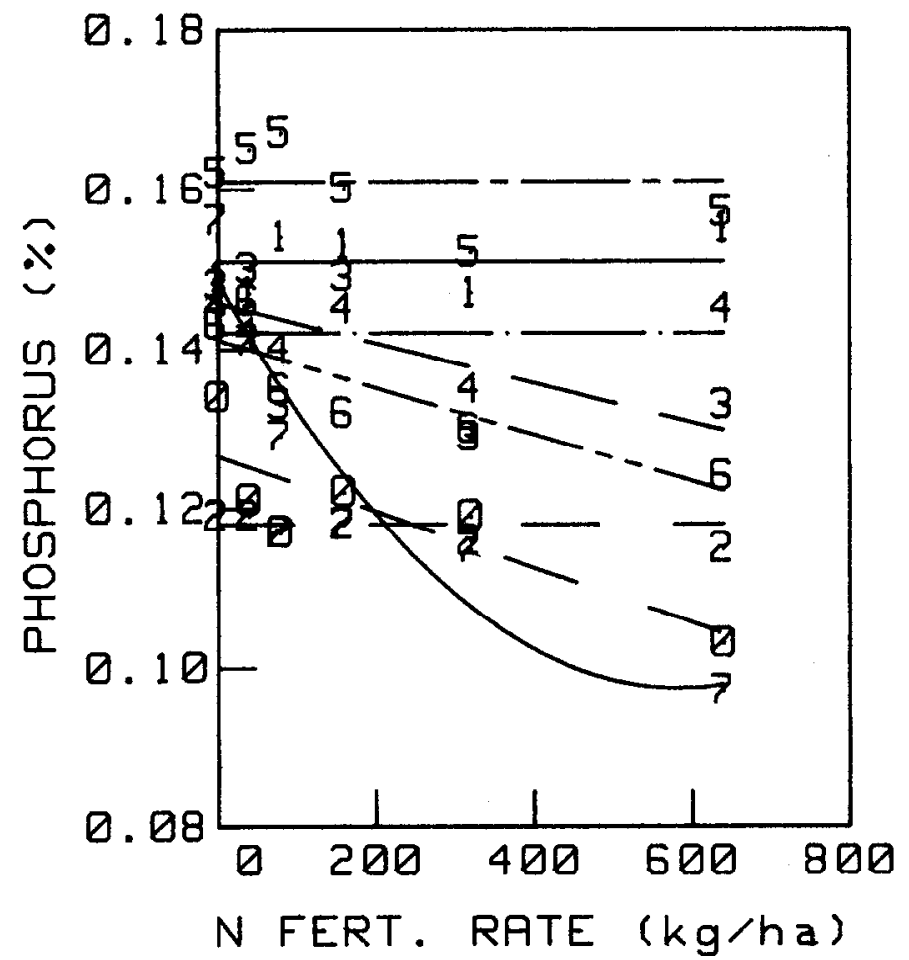

Fig. 4. Phosphorus of western wheatgrass near Sidney, Mont. during a 10-year period (numbers on lines represent years, $0=10$ th year) as affected by a single application of $0,40,80,160,320$, and $640 \mathrm{~kg} \mathrm{~N} /$ ha fertilizer in 1973. 
Accumulated over the 8-harvest years, all rates of $\mathrm{N}$ fertilizer increased CP yield by $0.87 \mathrm{~kg} / \mathrm{ha}$ per $\mathrm{kg}$ of $\mathrm{N}$ applied (Equation 5).

CP yield $(\mathrm{kg} / \mathrm{ha})=36.7+0.87 \times \mathrm{N}$ rate $(\mathrm{kg} / \mathrm{ha}), \mathrm{r}^{2}=0.97$.

This means that only $14 \%$ of the applied $\mathrm{N}$ was recovered as $\mathrm{N}$ in the plants at anthesis during the 8 years harvested. Application of $P$ fertilizer had no significant effect on the CP of western wheatgrass forage during the years measured $(1976,1978,1982)$.

\section{Phosphorus}

Nitrogen fertilization effects on the $P$ conc of western wheatgrass forage were not consistent over all years (significant year-by$\mathbf{N}$ interaction) (Table 2). In this study $\mathbf{N}$ fertilization had no effect on $P$ conc of forage the first two years nor the 4 th and 5 th years after application (Fig. 4). During the 3rd, 6th, and 10th years, N fertilization decreased the $\mathbf{P}$ conc from 0.025 to 0.035 percentage units per each $100 \mathrm{~kg} \mathrm{~N} /$ ha applied regardless of $\mathrm{N}$ rate. Nitrogen fertilization, however, decreased $P$ conc more per unit of $N$ applied at the lower $\mathrm{N}$ rates than at the higher rates during the 7 th year. It appears that application of $\mathbf{N}$ will decrease $\mathbf{P}$ conc of forage much longer than 10 years. Black and Wight (1979) also found that $N$ fertilization decreased the $P$ conc of native range forage the 8 years of their study. The P conc of western wheatgrass harvested at anthesis was never adequate to meet the minimum $P$ requirements of dry pregnant cows $(0.18 \%$; NRC 1976$)$.

Application of $P$ fertilizer in August 1975 increased $P$ conc of western wheatgrass forage an average of 0.04 percentage units in each of the three years the effect of $P$ fertilization was measured (1976, 1978, and 1982). Forage fertilized with $P$ contained adequate $P$ to meet the minimum $P$ requirements of dry pregnant cows two years (1976 and 1978) out of three.

\section{Conclusions}

Long-term research is necessary to determine the residual effects of $\mathbf{N}$ fertilization. In this study a single application of even low rates of $\mathbf{N}$ were still increasing forage yield and IVDMD while decreasing $P$ conc of western wheatgrass 10 years after application. Low rates of $\mathbf{N}$ fertilization affected $\mathrm{CP}$ conc for 6 years and $\mathrm{P}$ conc for more than 10 years. A single application of $\mathrm{N}$ increased accumulated forage yield over a 10-year period by $4.35 \mathrm{~kg} / \mathrm{ha}$ per $\mathrm{kg}$ of $\mathrm{N}$ applied. This was less than one-third of the forage yield response of native range to $\mathbf{N}$ fertilization during an eight year period (Wight and Black 1979). The greater response of native range to $\mathrm{N}$ fertilization was mostly due to the increased composition of western wheatgrass. Also the seeded stand of western wheatgrass may have responded less to $\mathbf{N}$ fertilization because of (1) summer fallowing the site for 2 years prior to seeding, (2) the site had been farmed for many years, and (3) difference in sampling methods. The native range was harvested to ground level whereas seeded western wheatgrass in this study was harvested leaving a $5 \mathrm{~cm}$ stubble height.

Evidence indicates that summer fallowing for 2 years before seeding had a greater effect on western wheatgrass forage yield and quality than $\mathbf{N}$ fertilization during the first 3 years harvested. Summer fallowing increased CP 8 percentage units during the first year over that present at the close of the study in 1982. This increased CP level gradually disappeared during the next 10 years. The application of even $640 \mathrm{~kg} \mathrm{~N} /$ ha only increased CP by 2 percentage units each year. Nitrogen fertilization is probably not needed on a seeded stand of grass until 3 to 4 years after seeding because two years of summer fallowing mineralized over $100 \mathrm{~kg} / \mathrm{ha}$ of nitrate-N.

The effects of $\mathrm{N}$ fertilization on IVDMD, CP and $\mathrm{P}$ in this study were less important to animal production than other factors. Application of $100 \mathrm{~kg} \mathrm{~N} /$ ha increased IVDMD by 0.1 percentage units whereas a one day delay in forage harvesting would have decreased IVDMD of floral and vegetative tillers of western heatgrass by 0.16 and 0.25 percentage units per day (White 1983). Generally CP was above the minimum level required by most beef cattle (10\%; NRC 1976). Increased CP would only slightly increase the digestible energy of the forage and therefore not have a measureable effect on livestock weight gains. After the effects of summer fallowing disappeared, residual $\mathrm{N}$ from fertilization significantly decreased $P$ conc of western wheatgrass except during the drought, thus intensifying a critical $P$ deficiency in the animal forage. Application of $P$ fertilizer increased the plant $P$ to provide the minimum $P$ requirements for dry pregnant cows two years out of the three that this value was measured.

\section{Literature Cited}

Binnie, R.C., F.J. Harrington, and J.C. Murdoch. 1974. The effect of cutting height and nitrogen level on the yield, in vitro digestibility and chemical composition of Italian ryegrass swards. J. Brit. Grassl. Soc. 29:57-62.

Black, A.L. 1968. Nitrogen and phosphorus fertilization for production of crested wheatgrass and native grass in northeastern Montana. Agron. J. 60:213-216.

Black, A.L., and J.R. Wight. 1979. Range fertilization: Nitrogen and phosphorus uptake and recovery over time. J. Range Manage. 32:349-353.

Calder, F.W., and L.B. MacLeod. 1968. In vitro digestibility of forage species as affected by fertilizer application, stage of development and harvest dates. Can. J. Plant Sci. 48:17-24.

Fribourg, H.A., N.C. Edwards, Jr., and K.M. Barth. 1971. In vitro drymatter digestibility of 'Midland' bermudagrass grown at several levels of N fertilization. Agron. J. 63:786-788.

Halvorson, A.D., and L.M. White. 1981. Nitrogen fertilization effects on seasonal $\mathrm{Ca}, \mathrm{Mg}, \mathrm{P}$, and $\mathrm{K}$ levels of western wheatgrass and green needlegrass. Agron. J. 73:651-656.

Halvorson, A.D., and L.M. White. 1983. Seasonal $\mathrm{Zn}, \mathrm{Cu}, \mathrm{Mn}$, and $\mathrm{Fe}$ levels of western wheatgrass and green needlegrass as affected by $N$ fertilization. Agron. J. 75:225-229.

Kilcher, M.R., S. Smoliak, W.A. Hubbard, A. Johnston, A.T.H. Gross, and E.V. McCurdy. 1965. Effects of inorganic nitrogen and phosphorus fertilizers on selected sites of native grassland in western Canada. Can. J. Plant Sci. 45:229-237.

Mason, J.L., and J.E. Miltimore. 1972. Ten year yield response of beardless wheatgrass from a single nitrogen application. J. Range Manage. 25:269-272.

Niehaus, M.H. 1971. Effect of $\mathrm{N}$ fertilizer on yield, crude protein content, and in vitro dry matter disappearance in Phalaris arundinacea $\mathrm{L}$. Agron. J. 63:793-794.

NRC (National Research Council: Subcommittee on Beef Cattle Nutrition). 1976. Nutrient requirements of beef cattle. Pub. 4. National Academy of Sciences-National Research Council, Washington, D.C.

Power, J.F. 1972. Fate of fertilizer N applied to a northern Great Plains rangeland ecosystem. J. Range Manage. 25:367-371.

Power, J.F. 1981. Long-term recovery of fertilizer nitrogen applied to a native mixed prairie. Soil Sci. Soc. Amer. J. 45:782-786.

Power, J.F., and J.O. Legg. 1984. Nitrogen-15 recovery for five years after application of ammonium nitrate to crested wheatgrass. Soil Sci. Soc. Amer. J. 48:322-326.

Read, D.W.L. 1969. Residual effects from fertilizer on native range in southwestern Saskatchewan. Can. J. Soil Sci. 49:225-230.

Rogler, G.A., and R.J. Lorenz. 1965. Nitrogen fertilization of natural grasslands in the northern plains of the United States. Proc. 9th Int. Grassl. Congr. (Sao Paul, Brazil). p. 1327-1330.

Smoliak, S. 1965. Effects of manure, straw and inorganic fertilizers on Northern Great Plains ranges. J. Range Manage. 18:11-15.

Steel, R.G.D., and J.H. Torrie. 1960. Analysis of variance III: Factorial experiments, p. 194-231. In: R.G.D. Steel and J.H. Torrie, Principles and procedures of statistics. McGraw-Hill, New York.

Taliaferro, C.M., F.P. Horn, B.B. Tucker, R. Totusek, and R.D. Morrison. 1975. Performance of three warm-season perennial grasses and a native range mixture as influenced by $\mathbf{N}$ and $\mathbf{P}$ fertilization. Agron. $J$. 67:289-292.

White, L.M. 1983. Seasonal changes in yield, digestibility, and crude protein of vegetative and floral tillers of two grasses. J. Range Manage. 36:402-405.

White, L.M. 1985. Stand age, precipitation, and temperature effects on forage yield. J. Range Manage. 38:39-43. 
White, L.M., and A.D. Halvorson. 1980. Nitrate levels in vegetative and floral tillers of western wheatgrass and green needlegrass as affected by nitrogen fertilization. Agron. J. 72:143-148.

White, L.M., and J.R. Wight. 1984. Forage yield and quality of dryland grasses and legumes. J. Range Manage. 37:233-236.

White, L.M., G.P. Hartman, and J.W. Bergman. 1981. In vitro digestibility, crude protein, and phosphorus content of straw of winter wheat, spring wheat, barley, and oat cultivars in eastern Montana. Agron. J. 73:117-121.
Wight, J.R. 1976. Range fertilization in the northern Great Plains. J. Range Manage. 29:180-185.

Wight, J.R., and A.L. Black. 1979. Range fertilization: Plant response and water use. J. Range Manage. 32:345-349. 